\title{
Detecting Financial Fraud Using Data Mining Techniques: A Decade Review from 2004 to 2015
}

\author{
Mousa Albashrawi ${ }^{1,2}$ \\ 1Department of Accounting \& Management Information Systems \\ 2Department of Operations \& Information Systems
}

\begin{abstract}
Objective: Financial fraud has been a big concern for many organizations across industries; billions of dollars are lost yearly because of this fraud. So businesses employ data mining techniques to address this continued and growing problem. This paper aims to review research studies conducted to detect financial fraud using data mining tools within one decade and communicate the current trends to academic scholars and industry practitioners.

Method: Various combinations of keywords were used to identify the pertinent articles. The majority of the articles retrieved from Science Direct but the search spanned other online databases (e.g., Emerald, Elsevier, World Scientific, IEEE, and Routledge - Taylor and Francis Group). Our search yielded a sample of 65 relevant articles (58 peer-reviewed journal articles with 7 conference papers). Onefifth of the articles was found in Expert Systems with Applications (ESA) while about one-tenth found in Decision Support Systems (DSS).

Results: 41 data mining techniques were used to detect fraud across different financial applications such as health insurance and credit card. Logistic regression model appeared to be the leading data mining tool in detecting financial fraud with a $13 \%$ of usage.In general, supervised learning tool have been used more frequently than the unsupervised ones. Financial statement fraud and bank fraud are the two largest financial applications being investigated in this area - about $63 \%$, which corresponds to 41 articles out of the 65 reviewed articles. Also, the two primary journal outlets for this topic are ESA and DSS.

Conclusion: This review provides a fast and easy-to-use source for both researchers and professionals, classifies financial fraud applications into a highlevel and detailed-level framework, shows the most significant data mining techniques in this domain, and reveals the most countries exposed to financial fraud.
\end{abstract}

Keywords: Financial fraud, fraud detection, data mining techniques, literature review.

\section{Introduction}

Financial fraud has been a big concern for many organizations across industries and in different countries since it brings huge devastations to business. Billions of dollars are lost yearly due to financial fraud; Bank of America, for example, agrees to pay $\$ 16.5$ billion for resolving financial fraud case [49]. Also, IRS (2014) indicates that Mr. Walker, the founder of Bixby Energy Systems, deceived more than 1,800 investors and committed multi-million dollar 
fraud. His fraudulent actions involve providing false statements of a) his subordinates' salaries and commissions; b) the operational capacity of the firm's core products, and c) an initial public stock offering [30]. Hence, the numbers still indicate this is a growing problem, which needs more attention from professionals and academicians.

Financial fraud detection tools have been brought to scenic in order to address this problem and to provide reliable solutions to business. Financial fraud is normally discovered through outlier detection process [32] enabled by data mining techniques, which also identify valuable information by revealing hidden trends, relationships, patterns found in a large database [25]. Data mining, defined as "a process that uses statistical, mathematical, artificial intelligence, and machine learning techniques to extract and identify useful information and subsequently gain knowledge from a large database" [50], is a major contributor for detecting different types of financial fraud through its diverse methods, such as, logistic regression, decision tree, support vector machine (SVM), neural network $(\mathrm{NN})$ and naïve Bayes. Some of these techniques outperform the others in specific financial contexts. Glancy and Yadav (2011) divide those contexts to three main areas: internal, insurance and credit [22]. Jans et al. (2011) further classify internal fraud into two categories: financial statement fraud and transaction fraud [31]. They define financial statement fraud as "the intentional misstatement of certain financial values to enhance the appearance of profitability and deceive shareholders or creditors" while transaction fraud captures the process of snatching organizational assets.

Although detecting financial fraud is considered a high priority for many organizations, the current literature lacks for an up-to-date, comprehensive and in-depth review that can help firms with their decisions of selecting the appropriate data mining technique. Ngai et al. (2011) provide a well-organized and detailed literature review on detecting financial fraud via data mining methods based on 49 articles ranging from 1997 to 2008 [50]. However, the specified time period is not able to capture the increasing trend of research in this area, specifically in the year of 2011, which is considered as a record year in financial fraud [11]. This has motivated us to extend Ngai et al.'s review and contribute by 1) revealing which context should implement what technique of data mining, 2) unfolding what technique can yield a higher classification accuracy in detecting financial fraud, 3) providing a new classification framework for financial fraud, and 4) expanding the sample of the reviewed articles to make it one of the most comprehensive reviews on this topic. Overall, this paper is an attempt to leverage our knowledge and to increase our understanding of data mining applications in financial fraud.

\section{Literature Review}

Due to its high importance, financial fraud has been given a considerable attention in prior research. Literature has tapped on different types of financial fraud using different methods of data mining. Table 1 presents the 65 examined articles in chronological order. From the table, we can determine what methods are being frequently implemented for which case of financial fraud and what method can work best across fraud types. For example, the logistic model can help in detecting financial fraud in automobile insurance, corporate insurance, financial statement, and credit card but it can be considered the best-performing method in the context of corporate insurance fraud.

Table 1: Summarized work for detecting financial fraud via data mining techniques (2004-2015)

\begin{tabular}{ccccc}
\hline No. Fraud Type & Dataset Used & $\begin{array}{c}\text { Data Mining } \\
\text { Technique Employed }\end{array}$ & Reference & $\begin{array}{c}\text { Best-Performing } \\
\text { Technique (Highest } \\
\text { Accuracy })^{\mathrm{a}}\end{array}$ \\
\hline
\end{tabular}




\begin{tabular}{|c|c|c|c|c|c|}
\hline 1 & $\begin{array}{c}\text { Financial } \\
\text { statement fraud }\end{array}$ & $\begin{array}{c}158 \text { firm } \\
\text { (79 fraud, } \\
79 \text { non-fraud): } 1982- \\
1999^{\mathbf{b}}\end{array}$ & Discriminant analysis & {$[35]$} & \\
\hline 2 & $\begin{array}{l}\text { Insurance auto } \\
\text { fraud }\end{array}$ & $\begin{array}{l}\text { 1,399 personal injury } \\
\text { protection (PIP) } \\
\text { automobile insurance } \\
\text { claims: } 1993\end{array}$ & Naïve Bayes & {$[68]$} & \\
\hline 3 & $\begin{array}{l}\text { Automobile } \\
\text { insurance fraud }\end{array}$ & $\begin{array}{l}4083 \text { cases ( } 245 \\
\text { fraud, } 3838 \text { non- } \\
\text { fraud) }\end{array}$ & $\begin{array}{l}\mathrm{NN} \text {, naïve Bayes and } \\
\text { decision tree }\end{array}$ & {$[56]$} & \\
\hline 4 & $\begin{array}{l}\text { Automobile } \\
\text { insurance fraud }\end{array}$ & $\begin{array}{c}\text { 1,399 PIP automobile } \\
\text { insurance claims: } \\
1993\end{array}$ & NN & {$[70]$} & \\
\hline 5 & $\begin{array}{l}\text { Automobile } \\
\text { insurance fraud }\end{array}$ & $\begin{array}{l}\text { Spanish automobile } \\
\text { insurance claims (half } \\
\text { fraud, half } \\
\text { legitimate): } \\
\text { 1993-1996 }\end{array}$ & Logit model & {$[6]$} & \\
\hline 6 & $\begin{array}{l}\text { Insurance auto } \\
\text { fraud }\end{array}$ & $\begin{array}{c}\text { Insurance } \\
\text { hypothetical data }\end{array}$ & Fuzzy logic & {$[54]$} & \\
\hline 7 & $\begin{array}{c}\text { Financial } \\
\text { statement fraud }\end{array}$ & $\begin{array}{l}27 \text { firms: } \\
2004-2005^{\mathbf{b}}\end{array}$ & Genetic algorithm & [37] & \\
\hline 8 & $\begin{array}{c}\text { Corporate } \\
\text { insurance fraud }\end{array}$ & $\begin{array}{c}\text { 82,807 firms from } \\
\text { RMA (US agency } \\
\text { under Dept. of } \\
\text { Agriculture): } 2001\end{array}$ & Logit and probit models & [33] & Logit model \\
\hline 9 & $\begin{array}{l}\text { Fraudulent } \\
\text { financial } \\
\text { statements }\end{array}$ & $\begin{array}{l}164 \text { Greek firms (41 } \\
\text { fraud, } 123 \text { non-fraud): } \\
2001-2002\end{array}$ & $\begin{array}{c}\text { Decision trees, NN, } \\
\text { Bayesian network, } \\
\text { SVM and nearest } \\
\text { neighbour }\end{array}$ & [40] & Decision tree \\
\hline 10 & $\begin{array}{l}\text { Health insurance } \\
\text { fraud }\end{array}$ & $\begin{array}{l}1812 \text { medical cases } \\
\text { (906 fraud, } 906 \text { non- } \\
\text { fraud ) }\end{array}$ & Process mining & {$[75]$} & \\
\hline 11 & Accounting fraud & 8000 public firms $^{\mathbf{b}}$ & $\begin{array}{l}\text { Logit model, K-means } \\
\text { clustering, and decision } \\
\text { tree }\end{array}$ & [71] & \\
\hline 12 & $\begin{array}{c}\text { Financial } \\
\text { statement fraud }\end{array}$ & $\begin{array}{l}\text { Real-world financial } \\
\text { data }^{\mathbf{b}}\end{array}$ & Genetic algorithm & {$[8]$} & \\
\hline 13 & Credit card fraud & $\begin{array}{l}50 \text { firms based on } \\
\text { questionnaire- } \\
\text { responded transaction } \\
\text { (QRT) data }\end{array}$ & SVM & [9] & \\
\hline 14 & $\begin{array}{l}\text { Fraudulent } \\
\text { financial } \\
\text { statements }\end{array}$ & $\begin{array}{c}76 \text { Greek } \\
\text { manufacturing } \\
\text { firms ( } 38 \text { fraud, } \\
38 \text { non-fraud) }\end{array}$ & $\begin{array}{l}\text { Decision trees, } \mathrm{NN} \text { and } \\
\text { Bayesian belief } \\
\text { networks }\end{array}$ & {$[38]$} & \\
\hline 15 & Money laundering & $\begin{array}{l}\text { Traditional suspicion } \\
\text { data (disgruntled } \\
\text { employees, banks, } \\
\text { and informants) }\end{array}$ & Network analysis & [19] & \\
\hline 16 & $\begin{array}{c}\text { Automobile } \\
\text { insurance fraud }\end{array}$ & $\begin{array}{l}2567 \text { suspicious } \\
\text { claims from Spanish } \\
\text { insurance company }\end{array}$ & Probit model & {$[57]$} & \\
\hline 17 & $\begin{array}{c}\text { Financial } \\
\text { statement fraud }\end{array}$ & $\begin{array}{l}312 \text { service-based } \\
\text { computer and } \\
\text { technology firms: } \\
1996-2001\end{array}$ & $\begin{array}{l}\text { Logit model and fuzzy } \\
\text { logic }\end{array}$ & {$[41]$} & \\
\hline 18 & $\begin{array}{c}\text { Financial } \\
\text { statement fraud }\end{array}$ & $\begin{array}{l}51 \text { fraudulent firms: } \\
1991-2003^{\mathbf{b}}\end{array}$ & Genetic algorithm & [27] & \\
\hline 19 & $\begin{array}{c}\text { Automobile } \\
\text { insurance fraud }\end{array}$ & $\begin{array}{c}2403 \text { claims }(2229 \\
\text { legitimate, } 174\end{array}$ & Logit model & [69] & \\
\hline
\end{tabular}




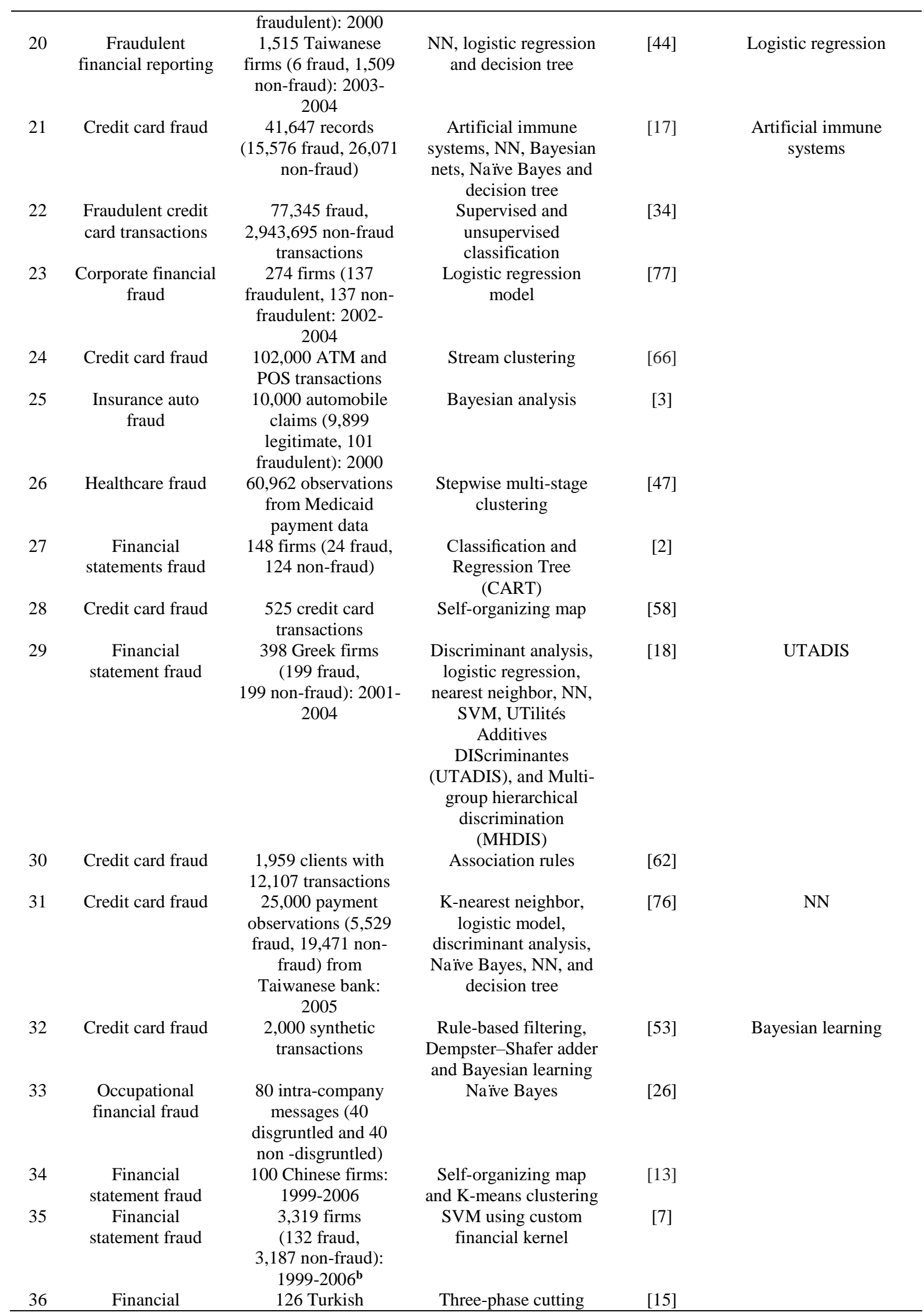




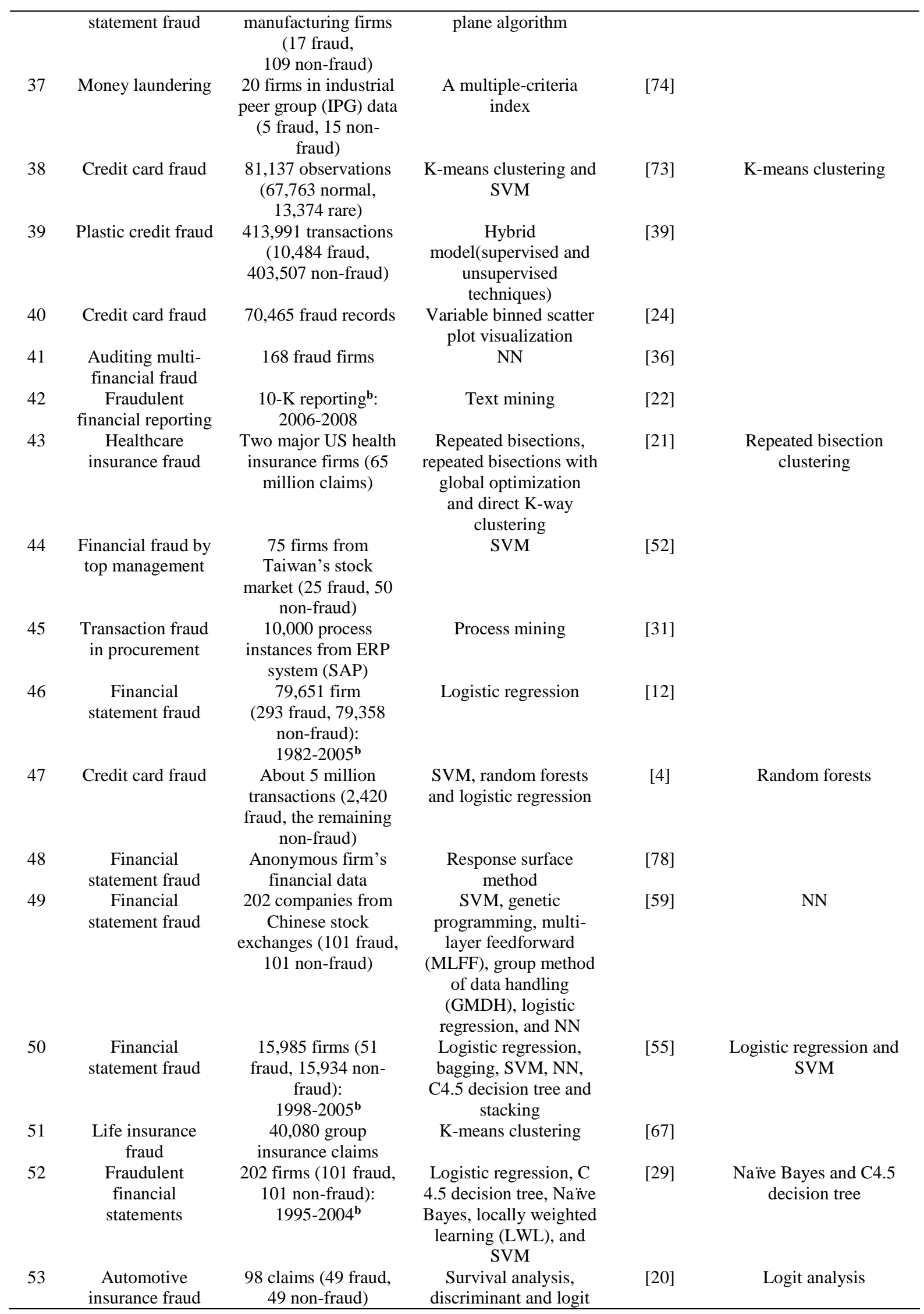




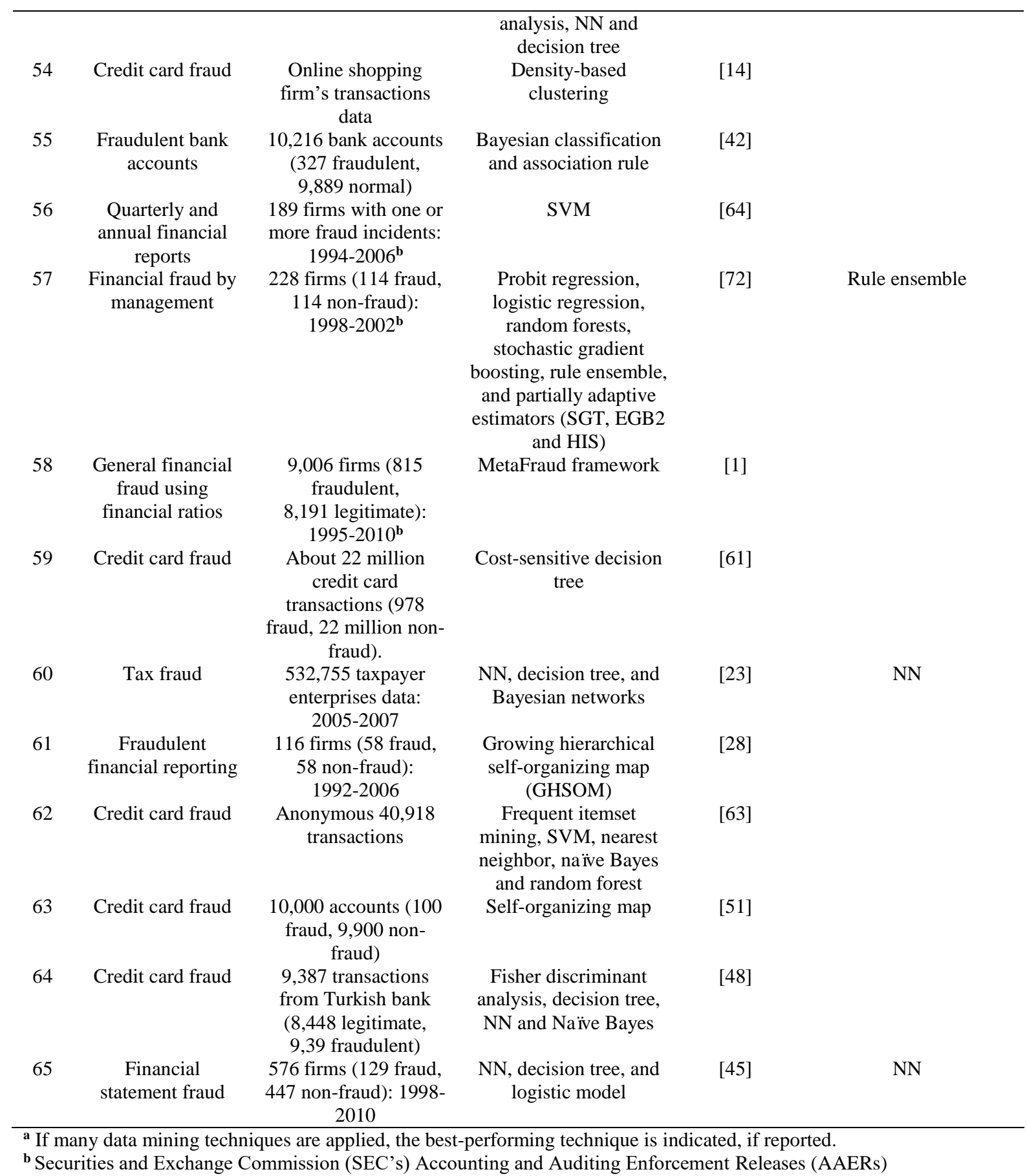

\section{Method}

A number of keywords was used to identify the pertinent articles, for instance, "detecting financial fraud, financial fraud and data mining, financial fraud detection, and detecting financial fraud via data mining". Most of the relevant articles were found in MIS related journals, e.g., Expert Systems with Applications and Decision Support Systems but some were found in finance and economic related journals, e.g., Journal of Risk and Insurance, and Applied 
Economics. Table 2 lists thirty-nine titles for both journals and conferences included in our analysis.

Although the majority of the articles retrieved from Science Direct, the search spanned other online databases (e.g., Emerald, Elsevier, World Scientific, IEEE, and Routledge - Taylor and Francis Group). Our search yielded a sample of 65 relevant articles (58 peer-reviewed journal articles with 7 conference papers). One-fifth of the articles was found in Expert Systems with Applications while about one-tenth found in Decision Support Systems (Table 2). Hence, these two journals have been the primary outlet for this topic. However, most of the articles had been conducted in the United States, followed by Taiwan, China and Spain (Table 3).

Table 2: Distribution of articles by journals and conferences (2004-2015)

\begin{tabular}{|c|c|c|}
\hline Journal/Conference Title & Frequency & Percentage (\%) \\
\hline Expert Systems with Applications & 13 & 20 \\
\hline Decision Support Systems & 6 & 9.23 \\
\hline Managerial Auditing Journal & 4 & 6.15 \\
\hline Knowledge-Based Systems & 3 & 4.62 \\
\hline The Journal of Risk and Insurance & 2 & 3.08 \\
\hline $\begin{array}{l}\text { ACM SIGKDD International Conference on Knowledge Discovery and } \\
\text { Data mining }\end{array}$ & 2 & 3.08 \\
\hline $\begin{array}{l}\text { International Journal of Intelligent Systems in Accounting and Finance } \\
\text { Management }\end{array}$ & 2 & 3.08 \\
\hline Computational Intelligence & 2 & 3.08 \\
\hline MIS Quarterly & 1 & 1.54 \\
\hline Management Science & 1 & 1.54 \\
\hline Contemporary Accounting Research & 1 & 1.54 \\
\hline Journal of Forecasting & 1 & 1.54 \\
\hline Journal of Data Science & 1 & 1.54 \\
\hline Computers in Human Behavior & 1 & 1.54 \\
\hline Information Fusion & 1 & 1.54 \\
\hline Journal of Practice \& Theory & 1 & 1.54 \\
\hline Journal of Economic Policy Reform & 1 & 1.54 \\
\hline IEEE Transaction on Knowledge and Data Engineering & 1 & 1.54 \\
\hline Journal of Money Laundering Control & 1 & 1.54 \\
\hline Journal of Pattern Recognition and Artificial Intelligence & 1 & 1.54 \\
\hline Insurance: Mathematics and Economics & 1 & 1.54 \\
\hline Journal of Information Technology \& Decision Making & 1 & 1.54 \\
\hline Applied Economics & 1 & 1.54 \\
\hline European Journal of Operational Research & 1 & 1.54 \\
\hline Data Mining and Knowledge Discovery & 1 & 1.54 \\
\hline International Journal of Computer Applications & 1 & 1.54 \\
\hline Data Mining IX & 1 & 1.54 \\
\hline Journal of Digital Accounting Research & 1 & 1.54 \\
\hline Journal of Emerging Technologies in Accounting & 1 & 1.54 \\
\hline Genetic and Evolutionary Computation Conference & 1 & 1.54 \\
\hline IEEE International Conference on Fuzzy System & 1 & 1.54 \\
\hline Computational Statistics: 18th Symposium (COMPSTAT 2008) & 1 & 1.54 \\
\hline Computational Statistics and Data Analysis & 1 & 1.54 \\
\hline International Journal of Management & 1 & 1.54 \\
\hline SPIE Electronic Imaging Conference & 1 & 1.54 \\
\hline IEEE International Conference on Granular Computing & 1 & 1.54 \\
\hline International Conference on Artificial Immune Systems & 1 & 1.54 \\
\hline The Scientific World Journal & 1 & 1.54 \\
\hline ACM SIGKDD Explorations & 1 & 1.54 \\
\hline Total & 65 & 100 \\
\hline
\end{tabular}

Table 3: The number of articles for detecting financial fraud by countries

\begin{tabular}{lll}
\hline Country & Frequency & Percentage $(\%)$ \\
\hline
\end{tabular}




\begin{tabular}{lcc}
\hline United States & 23 & 35.38 \\
Taiwan & 8 & 12.31 \\
China & 7 & 10.77 \\
Spain & 4 & 6.15 \\
Turkey & 3 & 4.62 \\
Greece & 3 & 4.62 \\
India & 3 & 4.62 \\
UK & 3 & 4.62 \\
Canada & 2 & 3.08 \\
Chile & 2 & 3.08 \\
Europe & 1 & 1.54 \\
Poland & 1 & 1.54 \\
France & 1 & 1.54 \\
Cyprus & 1 & 1.54 \\
Brazil & 1 & 1.54 \\
Singapore & 1 & 1.54 \\
Australia & 1 & 1.54 \\
\hline Total & $\mathbf{6 5}$ & $\mathbf{1 0 0}$
\end{tabular}

\section{Results}

This section highlights the most frequent data mining techniques used in financial fraud associated with their usage frequency, description and business application. Also, based on the reviewed different applications of financial fraud, this section provides a new classification scheme at two levels: high and detailed.

\subsection{Usage Frequency of Data Mining Techniques}

Out of 41 data mining techniques used in the reviewed articles, Table 4 shows the most applied ones in a period ranging from 2004 to 2015. Logistic regression model appears to be the leading data mining technique in detecting financial fraud with a $13 \%$, followed by both of neural network and decision tree, with a $11 \%$. While support vector machine is represented by a $9 \%$ and naïve Bayes is represented by a $6 \%$. Besides fraud detection, data mining techniques can address a wide array of business applications, for example, bankruptcy prediction, sales forecasting and scheduling optimization as shown in Table 4.

Table 4: Most used data mining methods, their usage frequency, description and general business application

\begin{tabular}{|c|c|c|c|c|}
\hline No. & Method & Frequency & Description & Business Application \\
\hline 1 & $\begin{array}{l}\text { Logistic } \\
\text { regression }\end{array}$ & 17 & $\begin{array}{l}\text { It is a typical classification method used to } \\
\text { generate dichotomous possible values [59]. }\end{array}$ & $\begin{array}{l}\text { Prediction of failure } \\
\text { probability in selling a } \\
\text { specific product }\end{array}$ \\
\hline 2 & Neural network & 15 & $\begin{array}{l}\text { ANN shows better results when testing large } \\
\text { sets of data. It consists of neurons or nodes } \\
\text { [43]. }\end{array}$ & Credit Rating \\
\hline 3 & Decision trees & 15 & $\begin{array}{l}\text { Decision tree or classification tree is a } \\
\text { method for assigning and classifying data } \\
\text { points into predefined clusters via splitting } \\
\text { rules [20]. }\end{array}$ & Stock market prediction \\
\hline 4 & $\begin{array}{l}\text { Support vector } \\
\text { machine }\end{array}$ & 12 & $\begin{array}{l}\text { SVM is a statistical method that used for } \\
\text { linear classification [4]. }\end{array}$ & Bankruptcy prediction \\
\hline 5 & Naïve Bayes & 8 & $\begin{array}{l}\text { This tool has the capability of predicting } \\
\text { group membership [26]. }\end{array}$ & Sentiment analysis \\
\hline 6 & Bayesian & 7 & "Directed acyclic graph, used to predict the & Tracking performance over \\
\hline
\end{tabular}




\begin{tabular}{|c|c|c|c|c|}
\hline & networks & & $\begin{array}{l}\text { likelihood of different outcomes, based on a } \\
\text { set of facts" [23]. }\end{array}$ & time \\
\hline 7 & $\begin{array}{l}\text { Discriminant } \\
\text { analysis }\end{array}$ & 6 & $\begin{array}{l}\text { This technique can predict group } \\
\text { membership of linearly combined variables } \\
{[65] \text {. }}\end{array}$ & Credit worthiness \\
\hline 8 & Nearest neighbor & 4 & $\begin{array}{l}\text { "New data points are classed according to } \\
\text { the classes of the points which are closest to } \\
\text { them in the training data" [5]. }\end{array}$ & Money laundering analysis \\
\hline 9 & $\begin{array}{l}\text { K-means } \\
\text { clustering }\end{array}$ & 4 & $\begin{array}{l}\mathrm{K} \text {-means is a clustering method that can } \\
\text { generate clusters with uniform shapes and it } \\
\text { is generally measured by squared Euclidean } \\
\text { distance [73]. }\end{array}$ & $\begin{array}{l}\text { Market price and cost } \\
\text { modeling }\end{array}$ \\
\hline 10 & $\begin{array}{l}\text { Self-organizing } \\
\text { map }\end{array}$ & 4 & $\begin{array}{l}\text { This technique, introduced by Kohonen, can } \\
\text { identify similarities between objects in } \\
\text { multidimensional space [51]. }\end{array}$ & $\begin{array}{l}\text { Project prioritization and } \\
\text { selection }\end{array}$ \\
\hline 11 & Random forests & 3 & $\begin{array}{l}\text { "A random forest is an ensemble of } \\
\text { unpruned classification or regression trees } \\
\text { induced from bootstrap samples of the } \\
\text { training data, using random feature selection } \\
\text { in the tree induction process" [4]. }\end{array}$ & Credit risk prediction \\
\hline 12 & Genetic algorithm & 3 & $\begin{array}{l}\text { This tool, an evolutionary computation } \\
\text { approach, can handle non-linear functions of } \\
\text { multiple variables [27]. }\end{array}$ & Marketing mix strategizing \\
\hline 13 & Probit model & 3 & $\begin{array}{l}\text { Probit model uses the assumption of a } \\
\text { symmetric distribution with fairly thin tails } \\
\text { [72]. }\end{array}$ & $\begin{array}{l}\text { Probability of marketing } \\
\text { campaign failure }\end{array}$ \\
\hline 14 & Association rules & 2 & $\begin{array}{l}\text { This tool uses "if" and "then" to unfold } \\
\text { related items [62]. }\end{array}$ & Market basket analysis \\
\hline 15 & Process mining & 2 & $\begin{array}{l}\text { This algorithm gives access to knowledge } \\
\text { via mining event logs to analyze system } \\
\text { processes [31]. }\end{array}$ & Fraud detection \\
\hline 16 & Fuzzy logic & 2 & $\begin{array}{l}\text { This algorithm can deal with human } \\
\text { reasoning and decision-making processes. }\end{array}$ & $\begin{array}{c}\text { Models for project risk } \\
\text { assessment }\end{array}$ \\
\hline
\end{tabular}

This table demonstrates that the supervised learning techniques (e.g., neural network, decision tree, support vector machine, and naïve Bayes) have been used more frequently than the unsupervised ones (e.g., clustering, association rules, and fuzzy logic). Thus, it could be stated that supervised learning techniques are better-performing tools than the unsupervised ones in detecting financial fraud.

\subsection{Classification Framework Based on Fraud Type}

Based on the analysis of the reviewed articles in this area, it is possible to classify financial fraud at a high-level into four major categories, namely, financial statement fraud, bank fraud, insurance fraud, and other related financial fraud (Table 5). The table shows the number of articles found in each type of financial fraud while the small pieces of pie chart represent those numbers in percentages. It is evident that financial statement fraud and bank fraud constitute the largest portion (63\%) - this percentage corresponds to 41 articles out of the 65 reviewed articles.

Table 5: Classification of fraud types examined by data mining methods in one decade

\begin{tabular}{|c|c|c|c|}
\hline $\begin{array}{l}\text { Fraud Type } \\
\text { (application) }\end{array}$ & $\begin{array}{l}\text { Article } \\
\text { Count }\end{array}$ & Description & Percentage in Chart \\
\hline $\begin{array}{l}\text { Financial statement } \\
\text { fraud }\end{array}$ & 21 & $\begin{array}{l}\text { This type of fraud is prevalent in today business world } \\
\text { and one of the biggest challenges faced by managers } \\
\text { and investors. It is basically the act of intentional or } \\
\text { irresponsible conducts and conveys deception or } \\
\text { misrepresentation; this produces materially misleading }\end{array}$ & $32 \%$ \\
\hline
\end{tabular}




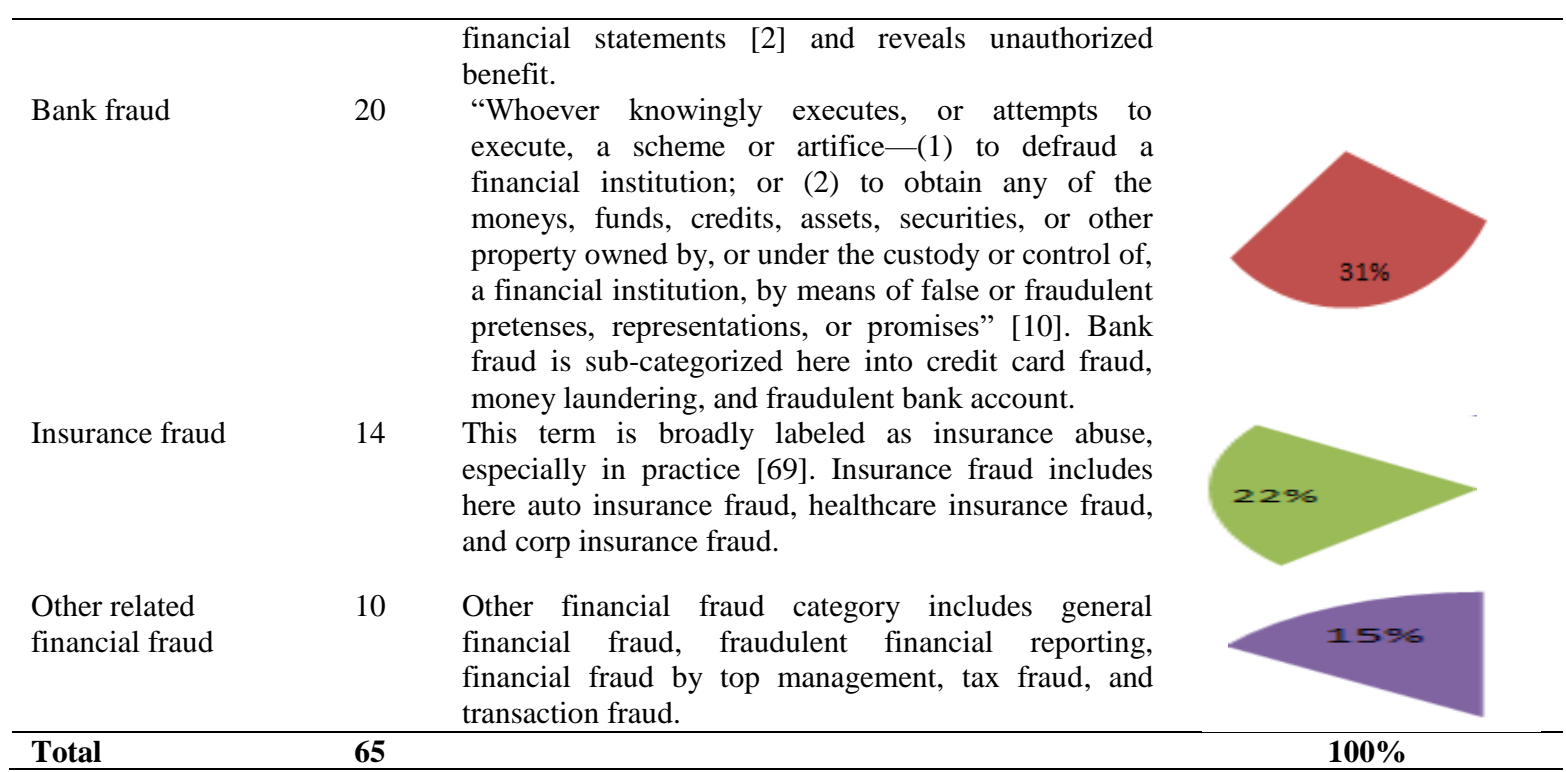

Table 6 further classifies and provides in-depth analysis by indicating the frequency of the sub-categories of financial fraud types. Bank fraud is subcategorized into credit card fraud, money laundering, and fraudulent bank account while insurance fraud is subcategorized into healthcare fraud, auto fraud, and corp fraud.

Table 6: Further break-down for fraud types with corresponding data mining techniques

\begin{tabular}{|c|c|c|c|c|c|c|c|c|}
\hline \multirow[t]{3}{*}{ Techniques } & \multicolumn{8}{|c|}{ Fraud Types } \\
\hline & \multirow[b]{2}{*}{$\begin{array}{c}\text { Financial } \\
\text { statement } \\
\text { fraud }\end{array}$} & \multicolumn{3}{|c|}{ Bank fraud } & \multicolumn{3}{|c|}{ Insurance fraud } & \multirow[b]{2}{*}{$\begin{array}{c}\text { Other } \\
\text { related } \\
\text { financial } \\
\text { fraud }\end{array}$} \\
\hline & & $\begin{array}{l}\text { Credit } \\
\text { card } \\
\text { fraud }\end{array}$ & $\begin{array}{c}\text { Money } \\
\text { laundering }\end{array}$ & $\begin{array}{c}\text { Fraudulent } \\
\text { bank } \\
\text { account }\end{array}$ & Healthcare & Auto & Corp & \\
\hline Logistic regression & 5 & 2 & & & & 3 & 2 & 1 \\
\hline Neural network & 4 & 3 & & & & 3 & & 4 \\
\hline Decision trees & 5 & 4 & & & & 2 & & 3 \\
\hline Discriminant analysis & 2 & 2 & & & & 1 & & 2 \\
\hline Bayesian networks & 2 & 3 & & 1 & & 1 & & 1 \\
\hline SVM & 3 & 3 & & & & & & 3 \\
\hline Nearest neighbor & 2 & 1 & & & & & & \\
\hline Association rules & & 1 & & 1 & & & & \\
\hline Rule-based filtering & & 1 & & & & & & \\
\hline $\begin{array}{l}\text { Dempster-Shafer } \\
\text { adder }\end{array}$ & & 1 & & & & & & \\
\hline Naïve Bayes & & 4 & & & & 2 & & 2 \\
\hline $\begin{array}{l}\text { Three-phase cutting } \\
\text { plane algorithm }\end{array}$ & 1 & & & & & & & \\
\hline $\begin{array}{l}\text { A multiple-criteria } \\
\text { index }\end{array}$ & & & 1 & & & & & \\
\hline Text mining & & & & & & & & 1 \\
\hline Process mining & & & & & 1 & & & 1 \\
\hline Random forests & & 2 & & & & & & 1 \\
\hline $\begin{array}{l}\text { Response surface } \\
\text { method }\end{array}$ & 1 & & & & & & & \\
\hline Genetic programming & 1 & & & & & & & \\
\hline MHDIS & 1 & & & & & & & \\
\hline GMDH & 1 & & & & & & & \\
\hline MLFF & 1 & & & & & & & \\
\hline LWL & 1 & & & & & & & \\
\hline
\end{tabular}


Bagging and Stacking

1

Stochastic gradient

boosting

Rule ensemble

MetaFraud

framework

Network analysis

Self-organizing map

Probit model

$\mathrm{K}$-means clustering

Density-based

clustering

Genetic algorithm

Stepwise multi-stage

clustering

Fuzzy logic

Repeated bisection

clustering

Stream clustering 1

Un/supervised 2

classification

Variable binned

scatter plot

Artificial immune

systems

Frequent itemset

mining

Survival analysis

The proposed classification framework can work as a reference in guiding financial fraud detection research through providing the help to scholars in identifying the demanding areas that need more attention. This framework can also provide industry professionals an index to select the appropriate data mining technique for a specific context of financial fraud. For example, firms that suffer from credit card fraud, they have an option of employing any of the supervised learning tools (i.e., naïve Bayes, decision tree, neural network, and SVM) and it is recommended to go with the most frequent used technique; decision tree. As noted, this selection is based on the fraud context and data mining technique frequency but it can be also based on performance (Table 2).

Table 7 and Chart 1: Yearly distribution of the articles on detecting financial fraud

\begin{tabular}{cc}
\hline Year & Amount \\
\hline 2004 & 3 \\
2005 & 5 \\
2006 & 5 \\
2007 & 6 \\
2008 & 9 \\
2009 & 6 \\
2010 & 7 \\
2011 & 12 \\
2012 & 5 \\
2013 & 2 \\
2014 & 3 \\
2015 & 2 \\
\hline Total & $\mathbf{6 5}$ \\
\hline
\end{tabular}

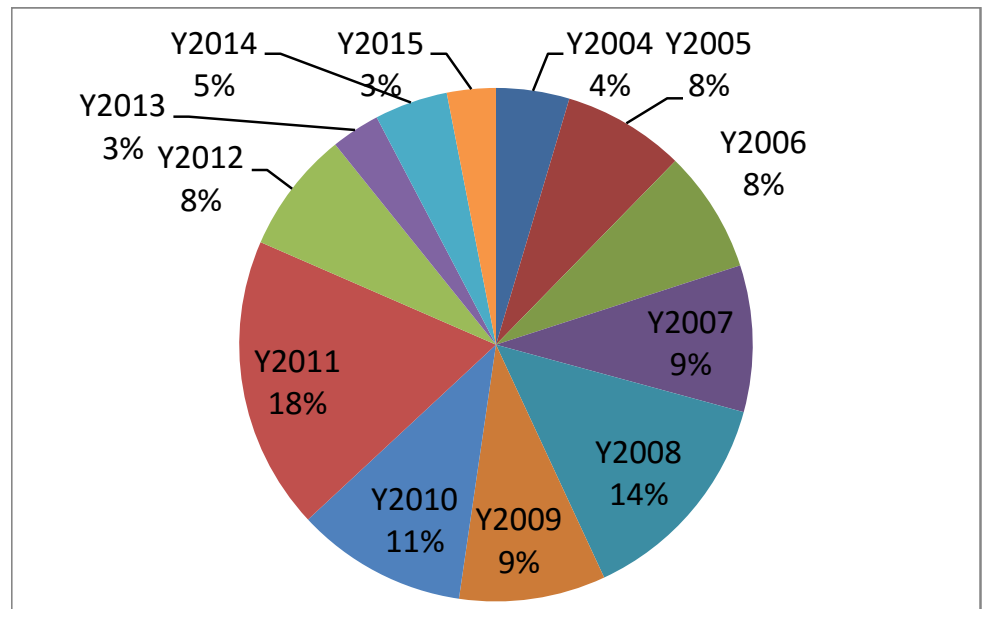


Table 7 and Chart 1 above highlight the yearly distribution of the 65 articles across the 10 year period. The gray highlighted years $(2008,2009,2010$ and 211) account for more than a half of publications in financial fraud detection. This high rate of publications reflects a serious growth in financial fraud across industries during these years. In particular, there had been a dramatic increase of the published papers during 2011. This increase seemed to be a natural response to the surge of fraud activities in that year; a 13\% increase of financial fraud in 2011 compared to the previous year [60]. Also, abc NEWS (2012) indicated that the year of 2011 is considered the worst year for financial fraud on record [11].

\section{Limitations and Conclusion}

This review has some limitations. First, it does not consider all sub-categories of financial fraud, i.e., advanced-fee fraud that targets a very large number of people who looks for "workfrom-home" opportunity. This fraud deceives people to pay a fee in advance so that they get the offer but once the fee is collected, they do not realize the expected benefits. Second, a decade review may not be sufficient to address this growing problem as it started when the business started. Third, the 65 articles explored may not reveal the entire story of data mining usage in the domain of financial fraud; several online databases need to be included in the sample for more powerful presentation and analysis.

However, it is crucial to have a wide-ranging review on detecting financial fraud in order to increase the understanding and to expand the knowledge of this area among researchers and professionals. This review sheds light on different valuable aspects of financial fraud detection:

- It provides a fast and easy-to-use source either for scholars or practitioners who are interested in the topic.

- It shows the importance of the investigated data mining techniques in the domain of financial fraud by presenting their frequency, usage percentage, and other general business applications. Although it is notable that logistic regression, decision tree, SVM, NN and Bayesian networks have been widely used (> 50\%) to detect financial fraud, they are not always associated with the best classification results.

- This review provides high-level and detailed classification frameworks of financial fraud. The high-level framework includes four major types - financial statement fraud, bank fraud, insurance fraud, and other related financial fraud. The detailed framework sub-classifies bank fraud to credit card fraud, money laundering, and account bank fraud and sub-classifies insurance fraud to healthcare fraud, auto fraud, and corp fraud. Combining the two frameworks into a single integrated catalog scheme can help to classify any new type of financial fraud. However, it is apparent that financial statement fraud has been the most examined type in this area. Thus, it is necessary for business firms to be more cautious when they audit or process their financial statements.

- This paper emphasizes the huge increase of research conducted to address financial fraud in the years of 2008, 2009, 2011 and 2012. These four years account approximately for more than $50 \%$ of the publications in the 10 -year period. More notably, the amount of research increased by $42 \%$ in 2011 compared to the previous year.

- Considering the country distribution table, it is possible to conclude that the countries (United States, Taiwan, China and Spain) that collectively had published $65 \%$ of the total articles on this topic, are being more exposed to it. In particular, the United States accounts for more than one-third (35\%) of the papers published in this area.

In sum, the highlighted aspects through this review can provide organizations with useful information regarding the various types of financial fraud and data mining techniques available 
to them. Organizations may be able to select the most suitable technique once considering its particular usage context, frequency, and performance. This could lead to achieving a higher level of accuracy in detecting financial fraud. Besides this benefit, researchers can take advantage of knowing the most frequent used methods and in which context so that they can develop a research project to either investigating such method in a different context or suggesting a new innovative method in a similar context. However, the primary contribution of this paper is twofold; the first is to provide an up-to-date and comprehensive analysis of this crucial topic as an extension to Ngai et al.'s review. The second is to provide scholars and practitioners with an excellent source of data mining applications used in financial fraud for their fast access and use.

\section{References}

[1] Abbasi A, Albrecht C, Vance A, Hansen J. Metafraud: A Meta-Learning Framework for Detecting Financial Fraud. MIS Quarterly 2012; 36: 1293-1327.

[2] Bai B, Yen J, Yang X. False Financial Statements: Characteristics of China's Listed Companies and CART Detecting Approach. International Journal of Information Technology \& Decision Making 2008; 7: 339-359.

[3] Bermúdez L, Pérez J, Ayuso M, Gómez E, Vázquez F. A Bayesian Dichotomous Model with Asymmetric Link for Fraud in Insurance. Insurance: Mathematics and Economics 2008; 42: 779-786.

[4] Bhattacharyya S, Jha S, Tharakunnel K, Westland, JC. Data Mining for Credit Card Fraud: A Comparative Study. Decision Support Systems 2011; 50: 602-613.

[5] Bidder OR, Campbell HA, Gómez-Laich A, Urgé P, Walker J, Cai Y, Wilson RP. Love Thy Neighbour: Automatic Animal Behavioural Classification of Acceleration Data Using the K-Nearest Neighbour Algorithm. PLoS ONE 2014; 9: 1-7.

[6] Caudill S, Ayuso M, Guill'en M. Fraud Detection Using A Multinomial Logit Model with Missing Information. The Journal of Risk and Insurance 2005; 72: 539-550.

[7] Cecchini M, Aytug H, Koehler G, Pathak P. Detecting Management Fraud in Public Companies. Management Science 2010; 56: 1146-1160.

[8] Chai W, Hoogs BK, Verschueren BT. Fuzzy Ranking of Financial Statements for Fraud Detection. In proceeding of IEEE International Conference on Fuzzy System 2006; 152 158.

[9] Chen R, Chen T, Lin C. A New Binary Support Vector System for Increasing Detection Rate of Credit Card Fraud. International Journal of Pattern Recognition and Artificial Intelligence 2006; 20: 227-239.

[10] Cornell University Law School, White-Collar Crime: An Overview. Retrieved from https://www.law.cornell.edu/uscode/text/18/1344, 2015.

[11] Curry C. 2011 Was Worst Year for Suspected Financial Crimes on Record. $a b c$ NEWS 2012; Retrieved from http://abcnews.go.com/Business/record-year-fraud-reports2011/story?id=15953781

[12] Dechow P, Ge W, Larson C, Sloan R. Predicting Material Accounting Misstatements. Contemporary Accounting Research 2011; 28: 1-16.

[13] Deng Q, Mei G. Combining Self-Organizing Map and K-Means Clustering for Detecting Fraudulent Financial Statements. In IEEE International Conference on Granular Computing 2009; 126-131.

[14] Dharwa JN, Patel AR. A Data Mining with Hybrid Approach Based Transaction Risk Score Generation Model (TRSGM) for Fraud Detection of Online Financial Transaction. International Journal of Computer Applications 2011; 16: 18-25. 
[15] Dikmen B, Küçükkocaoğlu G. The Detection of Earnings Manipulation: The Three-Phase Cutting Plane Algorithm Using Mathematical Programming. Journal of Forecasting 2010; 29: 442-466.

[16] Dimitras AI. Evaluation of Greek Construction Companies' Securities Using UTADIS Method. European Research Studies 2002; 95-107.

[17] Gadi MFA, Wang X, do Lago AP. Credit Card Fraud Detection with Artificial Immune System. In ICARIS '08 Proceedings of the 7th International Conference on Artificial Immune Systems 2008; 119-131

[18] Gaganis C. Classification Techniques for the Identification of Falsified Financial Statements: A Comparative Analysis. International Journal of Intelligent Systems in Accounting and Finance Management 2009; 16: 207-229.

[19] Gao Z, Ye M. A Framework for Data Mining-Based Anti-Money Laundering Research. Journal of Money Laundering Control 2007; 10: 170-179.

[20] Gepp A, Wilson JH, Kumar K, Bhattacharya S. A Comparative Analysis of Decision Trees Vis-a-vis Other Computational Data Mining Techniques in Automotive Insurance Fraud Detection. Journal of Data Science 2012; 10: 537-561.

[21] Ghani R, Kumar M. Interactive Learning for Efficiently Detecting Errors in Insurance Claims. In Proceedings of the 17th ACM SIGKDD International Conference on Knowledge Discovery and Data mining 2011; 325-333.

[22] Glancy FH, Yadav SB. A Computational Model for Financial Reporting Fraud Detection. Decision Support Systems 2011; 50: 595-601.

[23] González PC, Velásquez JD. Characterization and Detection of Taxpayers with False Invoices Using Data Mining Techniques. Expert Systems with Applications 2013; 40: 1427-1436.

[24] Hao MC, Dayal U, Sharma RK, Keim DA, Janetzko H. Visual Analytics of Large Multidimensional Data Using Variable Binned Scatter Plots. In IS\&T/SPIE Electronic Imaging 2010.

[25] Hassani H, Gheitanchi S, Yeganegi MR. On the Application of Data Mining to Official Data. Journal of Data Science 2010; 8: 75-89.

[26] Holton C. Identifying Disgruntled Employee Systems Fraud Risk Through Text Mining: A Simple Solution for a Multi-Billion Dollar Problem. Decision Support Systems 2009; 46: 853-864.

[27] Hoogs B, Kiehl T, Lacomb C, Senturk, D. A Genetic Algorithm Approach to Detecting Temporal Patterns Indicative of Financial Statement Fraud. Intelligent Systems in Accounting, Finance and Management 2007; 15: 41-56.

[28] Huang SY, Tsaih RH, Yu F. Topological Pattern Discovery and Feature Extraction for Fraudulent Financial Reporting. Expert Systems with Applications 2014; 41: 4360-4372.

[29] Humpherys SL, Moffitt KC, Burns MB, Burgoon JK, Felix WF. Identification of Fraudulent Financial Statements Using Linguistic Credibility Analysis. Decision Support Systems 2011; 50: 585-594.

[30] IRS. Examples of Corporate Fraud Investigations. Retrieved from IRS: http://www.irs.gov/uac/Examples-of--Corporate-Fraud-Investigations-Fiscal-Year-2014, 2014.

[31] Jans M, Werf JM, Lybaert N, Vanhoof K. A Business Process Mining Application for Internal Transaction Fraud Mitigation. Expert Systems with Applications 2011; 38: 1335113359.

[32] Jayakumar GDS, Thomas BJ. A New Procedure of Clustering based on Multivariate Outlier Detection. Journal of Data Science 2013; 11: 69-84.

[33] Jin Y, Rejesus R, Little B. Binary Choice Models for Rare Events Data: A Crop Insurance Fraud Application. Applied Economics 2005; 37: 841-848. 
[34] Juszczak P, Adams NM, Hand DJ, Whitrow C, Weston DJ. Off-the-Peg and Bespoke Classifiers for Fraud Detection. Computational Statistics and Data Analysis 2008; 52: 4521-4532.

[35] Kaminski KA, Wetzel TS, Guan L. Can Financial Ratios Detect Fraudulent Financial Reporting. Managerial Auditing Journal 2004; 19: 15-28.

[36] Kapardis MK, Christodoulou C, Agathocleous M. Neural Networks: The Panacea in Fraud Detection? Managerial Auditing Journal 2010; 25: 659-678.

[37] Kiehl TR, Hoogs BK, LaComb CA. Evolving Multi-Variate Time-Series Patterns for the Discrimination of Fraudulent Financial Filings. In Proc. of Genetic and Evolutionary Computation Conference 2005.

[38] Kirkos E, Spathis C, Manolopoulos Y. Data Mining Techniques for the Detection of Fraudulent Financial Statements. Expert Systems with Applications 2007; 32: 995-1003.

[39] Krivko M. A Hybrid Model for Plastic Card Fraud Detection Systems. Expert Systems with Applications 2010; 37: 6070-6076.

[40] Kotsiantis S, Koumanakos E, Tzelepis D, Tampakas V. Forecasting Fraudulent Financial Statements Using Data Mining. International Journal of Computational Intelligence 2006; 3: 104-110.

[41] Lenard MJ, Watkins AL, Alam P. Effective Use of Integrated Decision Making: An Advanced Technology Model for Evaluating Fraud in Service-Based Computer and Technology Firms. The Journal of Emerging Technologies in Accounting 2007; 4: 123-137.

[42] Li SH, Yen DC, Lu WH, Wang C. Identifying the Signs of Fraudulent Accounts Using Data Mining Techniques. Computers in Human Behavior 2012; 28: 1002-1013.

[43] Liao SH, Chu PH, Hsiao PY. Data Mining Techniques and Applications - A Decade Review from 2000 to 2011. Expert Systems with Applications 2012; 39: 11303-11311.

[44] Liou FM. Fraudulent Financial Reporting Detection and Business Failure Prediction Models: A Comparison. Managerial Auditing Journal 2008; 23: 650-662.

[45] Lin CC, Chiu AA, Huang SY, Yen DC. Detecting the Financial Statement Fraud: The Analysis of the Differences between Data Mining Techniques and Experts' Judgments. Knowledge-Based Systems 2015; 89: 459-470.

[46] Lin JW, Hwang MI, Becker JD. A Fuzzy Neural Network for Assessing the Risk of Fraudulent Financial Reporting. Managerial Auditing Journal 2003; 18: 657-665.

[47] Little B, Rejesus R, Schucking M, Harris R. Benford's Law, Data mining, and Financial Fraud: A Case Study in New York State Medicaid Data. Data Mining IX: Data Mining, Protection, Detection and Other Security Technologies 2008; 40:195-204.

[48] Mahmoudi N, Duman E. Detecting Credit Card Fraud by Modified Fisher Discriminant Analysis. Expert Systems with Applications 2015; 42: 2510-2516.

[49] Fox News. Bank of America pays $\$ 16.5$ bn to settle financial fraud case. Retrieved from Fox News Latino: http://latino.foxnews.com/latino/news/2014/08/21/bank-america-pays165-bn-to-settle-financial-fraud-case/, 2014.

[50] Ngai E, Hu Y, Wong Y, Chen Y, Sun X. The Application of Data Mining Techniques in Financial Fraud Detection: A Classification Framework and an Academic Review of Literature. Decision Support Systems 2011; 50: 559-569.

[51] Olszewski D. Fraud Detection Using Self-Organizing Map Visualizing the User Profiles. Knowledge-Based Systems 2014; 70: 324-334.

[52] Pai PF, Hsu MF, Wang MC. A Support Vector Machine-Based Model for Detecting Top Management Fraud. Knowledge-Based Systems 2011; 24: 314-321.

[53] Panigrahi S, Kundu A, Sural S, Majumdar A. Credit Card Fraud Detection: A Fusion Approach Using Dempster-Shafer Theory and Bayesian Learning. Information Fusion 2009; 10: 354-363. 
[54] Pathak J, Vidyarthi N, Summers SL. A Fuzzy-Based Algorithm for Auditors to Detect Elements of Fraud in Settled Insurance Claims. Managerial Auditing Journal 2005; 20: 632-644.

[55] Perols J. Financial Statement Fraud Detection: An Analysis of Statistical and Machine Learning Algorithms. Auditing: A Journal of Practice \& Theory 2011; 30: 19-50.

[56] Phua C, Alahakoon D, Lee V. Minority Report in Fraud Detection: Classification of Skewed Data. ACM SIGKDD Explorations Newsletter 2004; 6: 50-59.

[57] Pinquet J, Ayuso M, Guill'en M. Selection Bias and Auditing Policies for Insurance Claims. The Journal of Risk and Insurance 2007; 74: 425-440.

[58] Quah JT, Sriganesh M. Real-Time Credit Card Fraud Detection Using Computational Intelligence. Expert Systems with Applications 2008; 35: 1721-1732.

[59] Ravisankar P, Ravi V, Rao GR, Bose I. Detection of Financial Statement Fraud and Feature Selection Using Data Mining Techniques. Decision Support Systems 2011; 50: 491-500.

[60] Sabau AS. Survey of clustering based financial fraud detection research. Informatica Economica 2012; 16: 110.

[61] Sahin Y, Bulkan S, Duman E. A Cost-Sensitive Decision Tree Approach for Fraud Detection. Expert Systems with Applications 2013; 40: 5916-5923.

[62] Sánchez D, Vila M, Cerda L, Serrano J. Association Rules Applied to Credit Card Fraud Detection. Expert Systems with Applications 2009; 36: 3630-3640.

[63] Seeja KR, Zareapoor M. FraudMiner: A Novel Credit Card Fraud Detection Model Based on Frequent Itemset Mining. The Scientific World Journal 2014; 1-10.

[64] Skillicorn D, Purda L. Detecting Fraud in Financial Reports. European Intelligence and Security Informatics Conference 2012; 7-13.

[65] Stockburger DW. Discriminant Function Analysis. In Multivariate Statistics: Concepts, Models, and Applications 1998.

[66] Tasoulis D, Adams NM, Weston DJ, Hand DJ. Mining Information from Plastic Card Transaction Streams. In Proceedings in Computational Statistics: 18th Symposium (COMPSTAT 2008) 2008; 2: 315-322.

[67] Thiprungsri S, Vasarhelyi MA. Cluster Analysis for Anomaly Detection in Accounting Data: An Audit Approach. The International Journal of Digital Accounting Research 2011; 11: 69-84.

[68] Viaene S, Derrig R, Dedene G. A Case Study of Applying Boosting Naive Bayes to Claim Fraud Diagnosis. IEEE Transactions on Knowledge and Data Engineering 2004; 16: 612 620.

[69] Viaene S, Ayuso M, Guillen M, Gheel D, Dedene G. Strategies for Detecting Fraudulent Claims in the Automobile Insurance Industry. European Journal of Operational Research 2007, 176: 565-583.

[70] Viaenea S, Dedene G, Derrig R. Auto Claim Fraud Detection Using Bayesian Learning Neural Networks. Expert Systems with Applications 2005; 29: 653-666.

[71] Virdhagriswaran S, Dakin G. Camouflaged Fraud Detection in Domains with Complex Relationships. In Proceedings of the 12th ACM SIGKDD International Conference on Knowledge Discovery and Data Mining 2006; 941-947.

[72] Whiting DG, Hansen JV, Mcdonald JB, Albrecht C, Albrecht WS. Machine Learning Methods for Detecting Patterns of Management Fraud. Computational Intelligence 2012; 28: $505-527$.

[73] Wu J, Xiong H, Chen J. COG: Local Decomposition for Rare Class Analysis. Data Mining and Knowledge Discovery 2010; 20: 191-220.

[74] Yang S, Wei L. Detecting Money Laundering Using Filtering Techniques: A MultipleCriteria Index. Journal of Economic Policy Reform 2010; 13: 159-178.

[75] Yang W, Hwang S. A Process-Mining Framework for the Detection of Healthcare Fraud and Abuse. Expert Systems with Applications 2006; 31: 56-68. 
[76] Yeh I, Lien C. The Comparisons of Data Mining Techniques for the Predictive Accuracy of Probability of Default of Credit Card Clients. Expert Systems with Applications 2009; 36: 2473-2480.

[77] Yuan J, Yuan C, Deng Y, Yuan C. The Effects of Manager Compensation and Market Competition on Financial Fraud in Public Companies: An Empirical Study in China. International Journal of Management 2008; 25: 322-335.

[78] Zhou W, Kapoor G. Detecting Evolutionary Financial Statement Fraud. Decision Support Systems 2011; 50: 570-575.

Mousa Albashrawi

Department of Accounting \& Management Information Systems,

King Fahd University of Petroleum and Minerals,

Dhahran, Saudi Arabia

Department of Operations \& Information Systems,

University of Massachusetts Lowell, USA 
